\title{
Two new species of Araniella (Aranei: Araneidae) from Western Himalaya, with notes on species reported from India
}

\author{
Ава новых вида рода Araniella (Aranei: Araneidae) из Западных \\ Гимахаев, с комментариями о видах, отмеченных в Индии
}

\author{
Alireza Zamani ${ }^{1}$, Yuri M. Marusik ${ }^{2,3}$ \\ А. Замани ${ }^{1}$, Ю.М. Марусик ${ }^{2,3}$ \\ ${ }^{1}$ Zoological Museum, Biodiversity Unit, University of Turku, FI-20014, Finland. E-mail: zamani.alireza5@gmail.com
${ }^{2}$ Institute for Biological Problems of the North RAS, Portovaya Str.18, Magadan, 685000 Russia. E-mail: yurmar@mail.ru
${ }^{3}$ Department of Zoology \& Entomology, University of the Free State, Bloemfontein 9300, South Africa.
${ }^{2}$ Институт биологических проблем Севера ДВО РАН, Портовая 18, Магадан 685000 Россия.
}

KEY WORDS: Araneae, Araneus, Himachal Pradesh, Uttarakhand, orb-web spiders, new combination, Oriental realm.

КЛЮчЕВЫЕ СЛОВА: Araneae, Araneus, Химачал Прадеш, Уттаракханд, паук-кругопряд, новая комбинация, Ориентальное царство.

ABSTRACT: Araniella Chamberlin et Ivie, 1942 from India is surveyed. As a result, two new species, $A$. levii sp.n. and A. maasdorpi sp.n., are described on the basis of male specimens from high altitudes of Himachal Pradesh and Uttarakhand, northern India, and a new combination is established for Araniella nympha (Simon, 1889), comb.n. (ex. Araneus). Comments are provided for three other species known from this country.

How to cite this article: Zamani A., Marusik Yu.M. 2020. Two new species of Araniella (Aranei: Araneidae) from Western Himalaya, with notes on species reported from India // Arthropoda Selecta. Vol.29. No.3. P.361-366. doi: 10.15298/arthsel. 29.3.09

РЕЗЮМЕ: Сделан обзор пауков рода Araniella Chamberlin et Ivie, 1942 Индии. По самцам описаны два новых вида $A$. levii sp.n. и $A$. maasdorpi sp.n. Оба вида собраны в высокогорьях штата Химачал Прадеш и Уттаракханд, северная Индия. Установлена новая комбинация Araniella nympha (Simon, 1889), comb.n. (ex. Araneus). Приведены комментарии о трёх других видах рода известных из Индии.

\section{Introduction}

Araniella Chamberlin et Ivie, 1942 is a small araneid genus with 14 named species primarily distributed in the Palaearctic, two of which occur also in the Nearctic and two species are known from the northern part the Oriental realm [WSC, 2020]. Although only a few regional revisions dealing with the taxonomy of this group have been published (e.g. Levi, 1974; Blanke, 1982; Tanikawa, 1995; Zamani et al., 2020), it is con- sidered well-studied, with all species being known on the basis of both sexes (with the exception of A. nigromaculata (Schenkel, 1963), which is known only by the female holotype). Two Araniella species have been recorded from India: $A$. villanii Zamani, Marusik et Šestáková, 2020, known additionally from Iran and Kazakhstan, and A. cucurbitina (Clerck, 1757), although the record of this species is probably a misidentification. Recently, we had the opportunity to examine additional material of this genus from the Western Himalaya and detected two new species. Also, we recognized that one more species has been described from this region but currently classified in Araneus Clerck, 1757. The goal of this paper is to describe two new Araniella species and to provide comments on the other species of this genus known from India.

\section{Material and Methods}

Specimens were photographed using an Olympus Camedia E 520 camera attached to an Olympus SZX16 stereomicroscope at the Zoological Museum of University of Turku, Finland. Digital images were prepared using CombineZP image stacking software. Lengths of leg segments were measured on the dorsal side and given as: total length (femur, patella, tibia, metatarsus, tarsus). All measurements are given in millimetres. The depositories of the studied material are the Manchester Museum of the University of Manchester, England (MMUE; curator: Dmitri V. Logunov) and the Zoological Museum of Moscow University, Russia (ZMMU; curator: Kirill G. Mikhailov).

Abbreviations: ALE - anterior lateral eye, AME anterior median eye, PLE - posterior lateral eye, PME posterior median eye. 

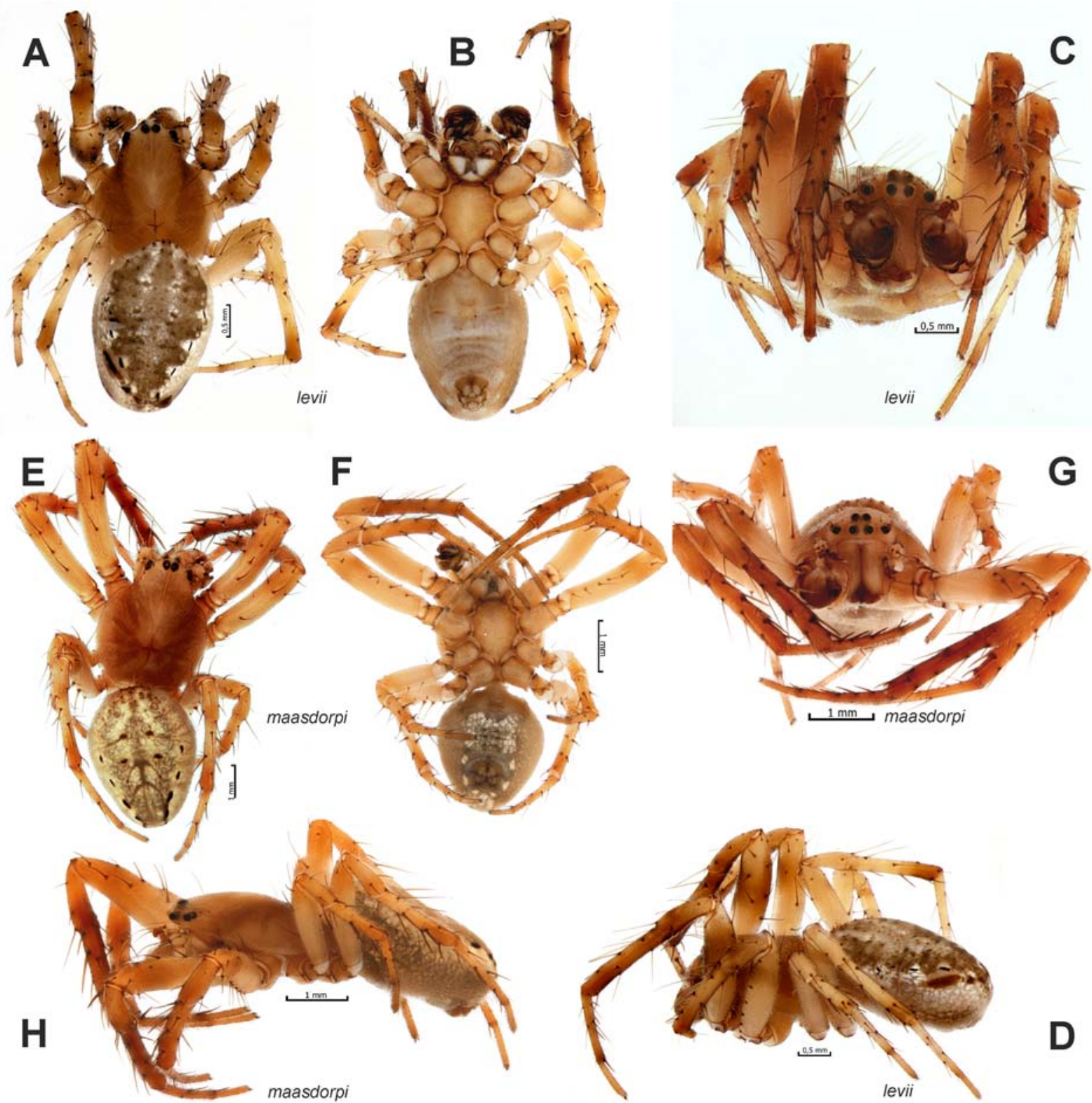

Fig. 1. General appearance of males of Araniella levii sp.n. (A-D) and A. maasdorpi sp.n. (E-H). A, E - dorsal; B, F - ventral; C, G anterior; D, H - lateral.

Рис. 1. Внешний вид самцов Araniella levii sp.n. (А-D) и A. maasdorpi sp.n. (Е-Н). А, Е — сверху; В, F - снизу; С, G спереди; D, Н - сбоку.

\section{Taxonomy}

Family Araneidae Clerck, 1757

Genus Araniella Chamberlin et Ivie, 1942

TYPE SPECIES. Epeira displicata Hentz, 1847 from Alabama, USA.

\section{Araniella levii sp.n.}

Figs $1 \mathrm{~A}-\mathrm{D}, 2 \mathrm{~A}-\mathrm{D}$.

TYPE MATERIAL. INDIA: Holotype $\sigma^{7}$ (MMUE), Himachal Pradesh: Tandi Vill., $5 \mathrm{~km} \mathrm{~S}$ of Keylong, $32^{\circ} 33^{\prime} 25.0^{\prime \prime} \mathrm{N} 76^{\circ} 58^{\prime}$
40.2"E, 2700 m, 11.06 .1999 (Yu.M. Marusik). Paratype: $1 \sigma^{7}$ (ZMMU), Jahalman Vill., 32³8’N 7651'E, 3000-3100 m, 13.06. 1999 (Yu.M. Marusik).

COMPARATIVE MATERIAL. Araniella inconspicua (Simon, 1874), Figs 3D-I: ENGLAND: $1 \sigma^{\top}$ (MMUE): Millyford Bridge heath, New Forest, swept from vegetation in heather, 18.05.1964 (J. Crocker). Araniella alpica (L. Koch, 1869), Fig. 3C: FRANCE: photograph of $O^{7}$ from Auvergne-Rhône-Alpes.

ETYMOLOGY. This species is named after Germanborn American arachnologist Herbert Levi (1921-2014) in recognition of his vast contributions to the taxonomy of Araneidae of the New World and Palaearctic.

DIAGNOSIS. The new species is similar to A alpica (Figs 2H, 3C), A. inconspicua (Fig. 3D-I), A. plicata Mi et 

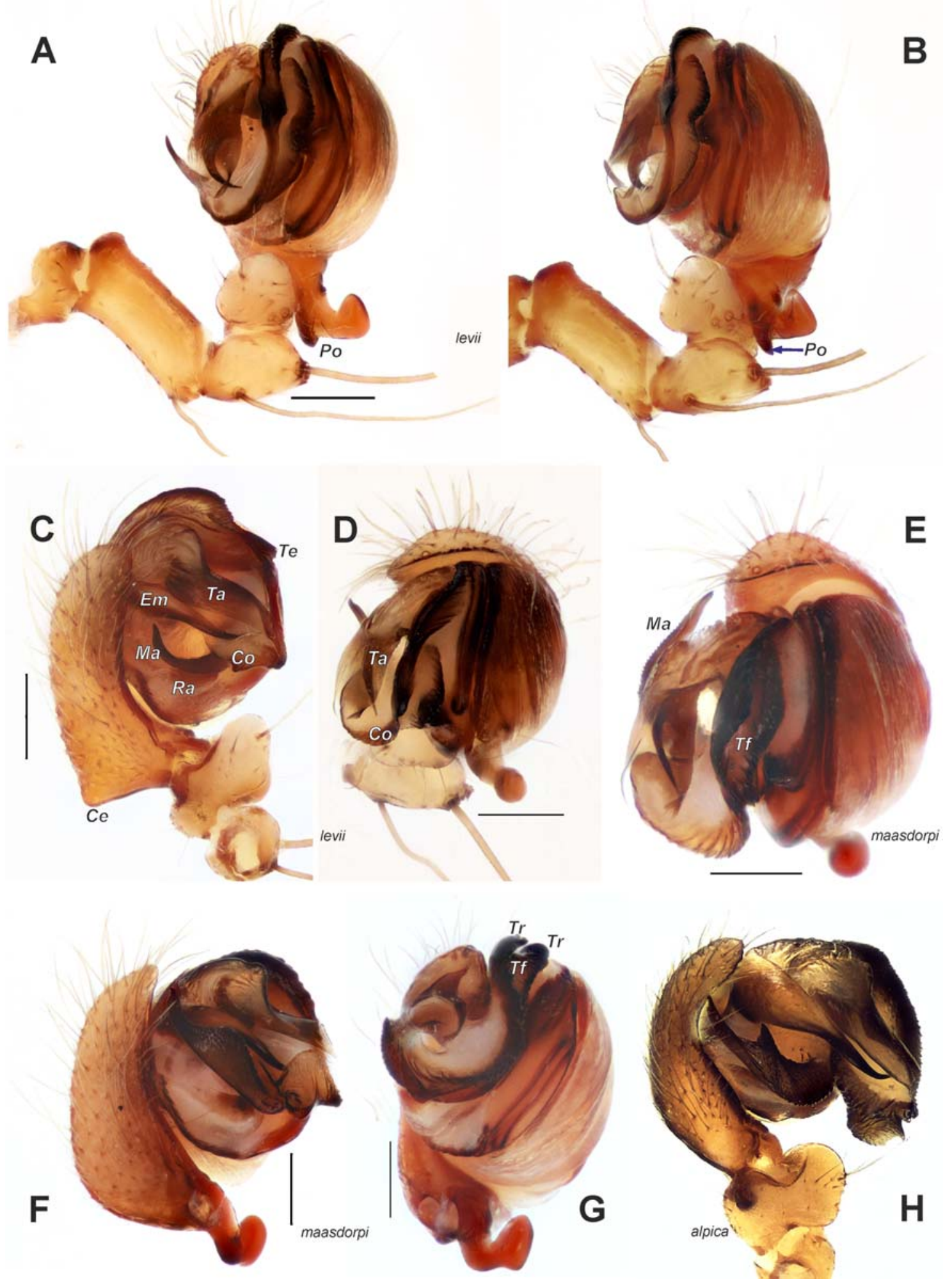

Fig. 2. Male palps of Araniella levii sp.n. (A-D), A. maasdorpi sp.n. (E-G) and A. alpica (H). A, B, G - retrolateral; C, F, H prolateral; D, E - apical. Abbreviations: $C e$ - dorsal extension of cymbium, $\mathrm{Co}$ - conductor, Em - embolus, $M a$ - median apophysis, $P o$ - outgrowth of paracymbium, $R a$ - radix, $T a$ - terminal apophysis, $T e$ - extension of tegulum, $T f$ - furrow of tegulum, $T r-$ tegular ridge. $\mathrm{H}$ - courtesy of P. Oger. Scale bars $=0.2 \mathrm{~mm}$.

Рис. 2. Пальпы самцов Araniella levii sp.n. (А-D), A. maasdorpi sp.n. (Е-G) и A. alpica (H). А, В, G - ретролатерально; C, F, Н пролатерально; D, Е - спереди. Сокращения: Ce - дорзальный вырост цимбиума, Co - кондуктор, Em - эмболюс, $M a-$ медиальный апофиз, Po - вырост парацимбиума, $R a-$ радикс, $T a$ - терминальный апофиз, $T e$ - вырост тегулюма, $T f-$ борозда тегулюма, $T r$ - гребень тегулюма. Н с разрешения P. Oger. Масштаб 0,2 мм. 
Peng, 2016 (figs 1-7 in Mi \& Peng [2016] and A. maasdorpi sp.n. (Figs $1 \mathrm{E}-\mathrm{H}, 2 \mathrm{E}-\mathrm{G}, 3 \mathrm{~A}-\mathrm{B}$ ) by having a broad (broader than the embolus) terminal apophysis $(T a)$ but differs from both by having an outgrowth of the paracymbium $(\mathrm{Po})$ and the cymbium having a dorsal extension $(\mathrm{Ce})$ forming a right angle in ventral view (vs. paracymbium without outgrowth and cymbium smoothly rounded).

DESCRIPTION. Male (Holotype). Habitus as in Fig. 1A-D. Total length 4.22, carapace 2.07 long, 1.02 wide at pars cephalica, 1.76 at pars thoracica. Eye sizes and interdistances: AME 0.13, PME 0.09, ALE 0.09, PLE 0.10, AMEAME 0.15, AME-ALE 0.21, PME-PME 0.09. Carapace, sternum, labium, chelicerae, and maxillae reddish brown, lighter ventrally, carapace with two broad, dark submarginal bands. Legs III and IV lighter than carapace, distally with dark, broad annulations. Abdomen with dark gray dorsal folium (stored in alcohol, probably green in live specimens), posterodorsally with four pairs of black lateral spots; venter pale, lacking white guanine spots. Spinnerets light brown, apical segment lighter.

Leg measurements: I: $6.95(2.11,1.08,1.61,1.45,0.70)$, II: $5.74+$ missing tarsus $(1.99,0.94,1.38,1.43$, missing), III: 4.41 (1.42, 0.67, 0.83, 0.92, 0.57), IV: 5.93 (1.80, 0.79, $1.32,1.44,0.58)$.

Palp as in Fig. 2A-D; femur 2.4 times longer than wide with one macroseta, patella 1.5 times shorter than femur, with 3 macrosetae; tibia slightly shorter than patella, with retrolateral extension; cymbium with dorsal extension $(\mathrm{Ce})$ forming right angle (in prolateral view, Fig. 2C), paracymbium with outgrowth $(\mathrm{Po})$ at basal part, outgrowth directed posteriorly; tegulum (in ventral view) rounded near base, mesal part straight with angular extension $(T e)$, terminal part straight; radix $(R a)$ semicircular; median apophysis $(M a)$ tusk-like, surface with fine granulation; conductor $(C o)$ with one distinct spike; terminal apophysis broad (wider than embolus), with rounded base and parallel margins, terminal part tapering; embolus straight with sharply pointed tip.

Female. Unknown.

DISTRIBUTION. Known only from two nearby localities at high altitudes of Himachal Pradesh State, Western Himalaya, northern India.

\section{Araniella maasdorpi sp.n.}

Figs $1 \mathrm{E}-\mathrm{H}, 2 \mathrm{E}-\mathrm{G}, 3 \mathrm{~A}-\mathrm{B}$.

TYPE MATERIAL. INDIA: Holotype $\sigma^{7}$ (MMUE), Uttarakhand State: Gobind Dham Vill., 30 $40^{\circ} \mathrm{N} 79^{\circ} 35^{\prime} \mathrm{E}, 3150-3300 \mathrm{~m}$, 20-23.05.1999 (Yu.M. Marusik). Paratypes: $2 \mathrm{O}^{7} \mathrm{O}^{7}$ (ZMMU), $\mathrm{Hi}-$ machal Pradesh State: Keylong, $32^{\circ} 34^{\prime} \mathrm{N} 77^{\circ} 01^{\prime} \mathrm{E}, 3100-3400 \mathrm{~m}$, 12-17.06.1999 (Yu.M. Marusik).

ETYMOLOGY. The species is named after Burton Maasdorp (University of the Free State, Bloemfontein, South Africa) for his assistance in managing financial reports to the university, to which the author Y.M. is affiliated.

DIAGNOSIS. The new species is most similar to $A$. alpica by having a modified median apophysis and differs by the shorter terminal apophysis (cf. Figs $2 \mathrm{~F}$ and $2 \mathrm{H}$ ) and the median apophysis with a widened mid-part lacking a spine-like outgrowth ( $v s$. mid-part not widened and with a spine-like outgrowth directed anteriorly).

DESCRIPTION. Male (Holotype). Habitus as in Fig. 1E-H. Total length 4.98, carapace 2.43 long, 1.06 wide at pars cephalica, 1.94 at pars thoracica. Eye sizes and interdistances: AME 0.14, PME 0.10, ALE 0.09, PLE 0.12, AMEAME 0.17, AME-ALE 0.22, PME-PME 0.08. Carapace, sternum, labium, chelicerae, and maxillae reddish brown, lighter ventrally; carapace with two broad, dark submarginal bands. Legs lighter in color than the carapace, distally with dark, broad annulations. Abdomen cream (stored in alcohol, probably green in live specimens) dorsally, posterodorsally with four pairs of black lateral spots; venter pale with white guanine spots mesoventrally and around spinnerets. Spinnerets light brown, apical segments lighter.

Leg measurements: I: $7.41(2.25,1.15,1.71,1.59,0.71)$, II: $7.08(2.15,1.04,1.48,1.67,0.74)$, III: $4.72(1.47,0.76$, $0.89,1.03,0.57)$, IV: $6.81(2.01,0.92,1.53,1.67,0.68)$.

Palp as in Figs 2E-G, 3A-B; cymbium and paracymbium unmodified; tegulum rounded in ventral view (Fig. 2G), basal part with longitudinal furrow (Tf) forming 2 tegular ridges $(T r)$; median apophysis strongly modified, with widened mid-part and cuticle covered with slender spines (Fig. $2 \mathrm{E})$; conductor with one spike and one rounded tip; embolus sharply pointed.

Female. Unknown.

DISTRIBUTION. Known only from two localities at high altitudes of Uttarakhand and Himachal Pradesh States, Western Himalaya, northern India.

\section{Araniella nympha (Simon, 1889), comb.n.}

Epeira nympha Simon, 1889: 339 (†).

Araneus nympha: Tikader, Bal, 1981: 55, figs 121-124 (); Tikader, 1982: 235, figs 458-461 (†) (in both works, the illustrated material is the holotype); $\mathrm{Hu}, \mathrm{Li}, 1987: 263$, fig. 10.1-4 (+); Yin et al., 1997: 148, fig. 63a-d (+); Song et al., 1999: 240, figs 139J-L, $148 \mathrm{~N}(+)$. (all three reproduced figures from Tikader [1982]); $\mathrm{Hu}$, 2001: 445, figs 289.1-4, 290.1-4 (ㅇ, reproduced figures from Tikader [1982] and description of $0^{7}$ ); Sen et al., 2015: 121, figs 765-770, pl. 23 ().

COMMENTS. This species was described from Uttarakhand, northern India based on the holotype female collected at an elevation of more than $2300 \mathrm{~m}$ [Simon, 1889]. The original description doesn't include any illustrations; however, Dyal [1935] reported it from the Lahore lowlands, Pakistani Punjab, based on a juvenile specimen. Figures of the epigyne of the holotype provided by Tikader \& Bal (1981) leave no doubt that this species belongs to Araniella, and therefore we transfer it from Araneus, establishing a new combination. All other figures of this species are based on material from India and China, except for those of the male [Hu, 2001], and those given by Sen et al. [2015] are reproduced after Tikader \& Bal [1981]. Figures of the male by $\mathrm{Hu}$ [2001] are very schematic and this specimen could belong to another genus. Currently this species is known from northern India, Pakistani Punjab and Xizang, China [Li, Lin, 2016]; however, records from outside of Uttarakhand most likely belong to other species or even other genera.

The epigyne of this species is similar to that of $A$. villanii but differs by the scape having a middle incision (vs. widened) and being relatively narrow (two times narrower than base $v s .1 .5$ times narrower than base).

Araniella villanii Zamani, Marusik et Šestáková, 2020

Araniella villanii Zamani et al., 2020: 18, figs 1B, D, 3A-B, 4C-D, 5A-B, 7A, 8A, 9A, 10A ( ( $\left.^{7}+\right)$.

COMMENTS. Ten paratype specimens of this species have been collected from southwest Iran, southeast Kazakhstan and northern India (Himachal Pradesh). 

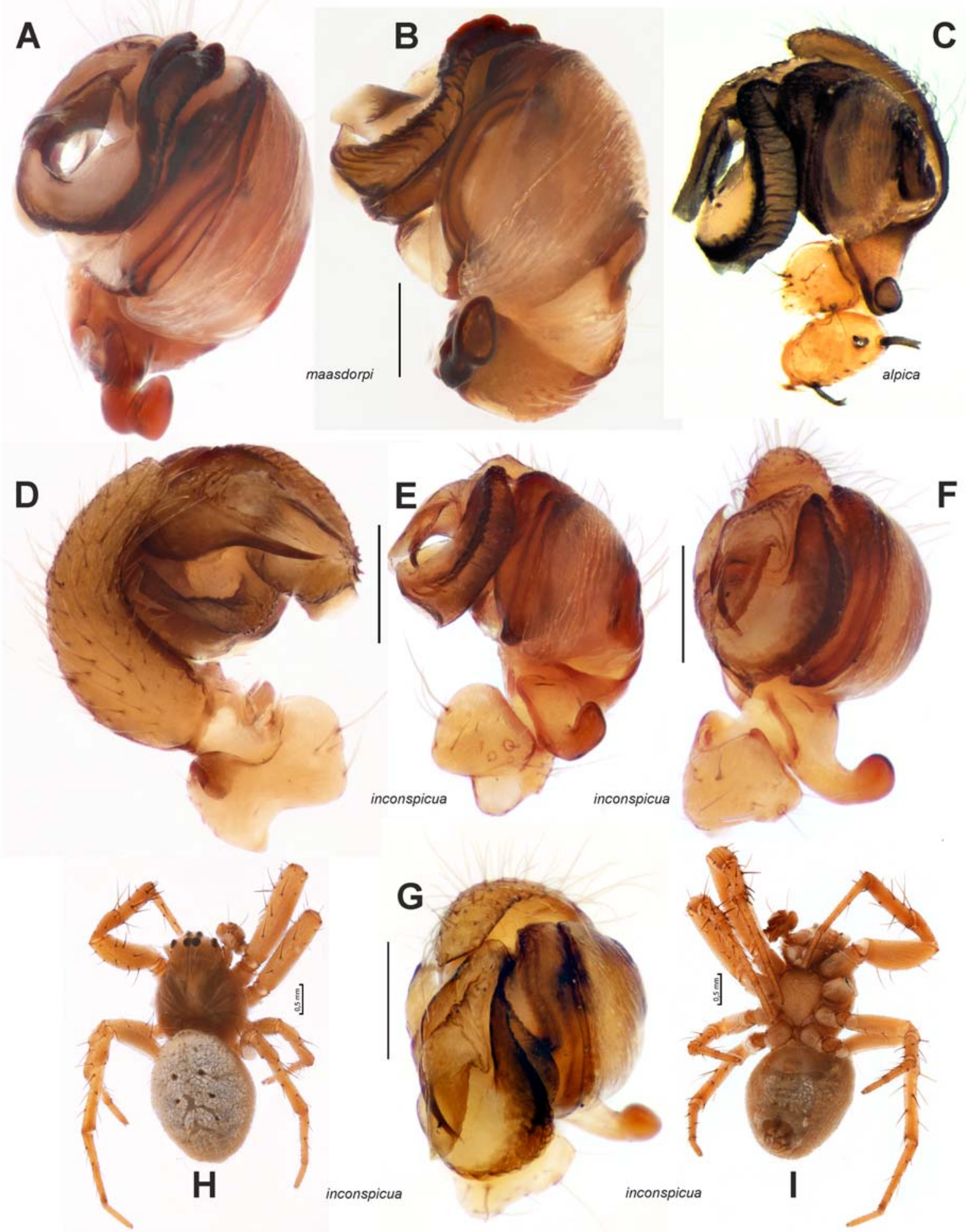

Fig. 3. Males of Araniella maasdorpi sp.n. (A-B), A. alpica (C) and A. inconspicua (D-I). A-C, E - palp, retrolateral; D, G - same, prolateral and apical; $\mathrm{H}-\mathrm{I}$ - habitus, dorsal and ventral. C - courtesy of P. Oger. Scale bars $=0.2 \mathrm{~mm}$, unless stated otherwise.

Рис. 3. Самцы Araniella maasdorpi sp.n. (A-B), A. alpica (C) и A. inconspicua (D-I). А-C, E - пальпа, ретролатерально; D, Gпальпа, пролатерально и апикально; H-I - габитус, сверху и снизу. C с разрешения P. Oger. Масштаб 0,2 мм, если не указано иначе. 


\section{Araniella cucurbitina (Clerck, 1757)}

Araneus cucurbitinus typicus Kulczyński, 1905: 232, pl. 7, figs $1,11,15-16,25$ ( $\bigcirc^{7}+$ ).

Araneus cucurbitinus: Blanke, 1976: 77, figs 1a, 2a, 3a, 4a $\left(\sigma^{\top}+\right)$; Blanke, 1980: 97, figs 1, 4, 7 ( $\sigma^{7}+$ ); Tikader, Bal, 1981: 56 , figs $125-128(\rightarrow$, seems misidentified).

Araniella cucurbitina: Blanke, 1982: 289, figs 3a-b, 5a-b, $6 \mathrm{a}-\mathrm{b}, 8 \mathrm{a}\left(\mathrm{O}^{7}+\right)$.

For the complete list of references see WSC [2020].

COMMENTS. There is a single record of this species from India (from Shillong, Meghalaya). This record is based on a single female and most probably refers to another species.

Acknowledgments. YM is grateful to Seppo Koponen and Ilari E. Sääksjärvi (Zoological Museum, University of Turku) for permission to use museum facilities and arranging his visit to Turku. Dmitri Logunov (MMUE) and Pierre Oger (Belgium) kindly provided comparative material and figures used in this study. Akio Tanikawa (Tokyo, Japan) and Seppo Koponen commented on an earlier draft of the manuscript, and Mikhail M. Omelko (Vladivostok, Russia) and Alexander A. Fomichev (Barnaul, Russia) reviewed the paper. The English of the final draft was checked and corrected by Sarah Crews (San Francisco, USA).

\section{References}

Blanke R. 1976. Morphologisch-ethologische Divergenzen und Anwendung des Biospecies-Konzepts bei Angehörigen der Kreuzspinnen-Gattung Araneus (Arachnida: Araneae: Araneidae) // Entomologica Germanica. Bd.3. S.77-82.

Blanke R. 1980. Die systematische Stellung von Araneus cucurbitinus maderianus Kulczyński 1905 (Arachnida: Araneae) // Senckenbergiana Biologica. Bd.61. S.97-102.

Blanke R. 1982. Untersuchungen zur Taxonomie der Gattung Araniella (Araneae, Araneidae) // Zoologica Scripta. Vol.11. No.4. S.287-305.

Dyal S. 1935. Fauna of Lahore. 4.-Spiders of Lahore // Bulletin of the Department of Zoology of the Panjab University. Vol.1. P.119-252.

$\mathrm{Hu}$ J.L. 2001. Spiders in Qinghai-Tibet Plateau of China. Henan Science and Technology Publishing House. 658 pp.
Hu J.L., Li A.H. 1987. The spiders collected from the fields and the forests of Xizang Autonomous Region, China. (II) // Agricultural Insects, Spiders, Plant Diseases and Weeds of Xizang. Vol.2. P.247-353.

Kulczyński W. 1905. Fragmenta arachnologica. V. // Bulletin International de l'Academie des Sciences de Cracovie. Vol.1905. P.231-250.

Levi H.W. 1974. The orb-weaver genera Araniella and Nuctenea (Araneae: Araneidae) // Bulletin of the Museum of Comparative Zoology. Vol.146. P.291-316.

Li S.Q., Lin Y.C. 2016. Species Catalogue of China. Volume 3. Animalia. Invertebrata (I). Arachnida: Araneae. Beijing: Science Press. 578 p. [In Chinese]

Mi X.Q., Peng X.J. 2016. A new species of the genus Araniella Chamberlin \& Ivie, 1942 (Araneae: Araneidae) from southwest China // Oriental Insects. Vol.50. No.1. P.34-39.

Sen S., Dhali D.C., Saha S., Raychaudhuri D. 2015. Spiders (Araneae: Arachnida) of Reserve Forests of Dooars: Gorumara National Park, Chapramari Wildlife Sanctuary and Mahananda Wildlife Sanctuary // World Scientific News. Vol.20. P.1-339.

Simon E. 1889. Arachnides de 1'Himalaya, recueillis par MM. Oldham et Wood-Mason, et faisant partie des collections de l'Indian Museum. Première partie // Journal of the Asiatic Society of Bengal, part II (Natural science). Vol.58. P.334344.

Song D.X., Zhu M.S., Chen J. 1999. The spiders of China. Shijiazhuang: Hebei Science and Technology Publishing House. 640 pp.

Tanikawa A. 1995. A revision of the Japanese spiders of the genus Araniella (Araneae: Araneidae) // Acta Arachnologica. Vol.44. No.1. P.51-60.

Tikader B.K. 1982. Part 1. Family Araneidae (= Argiopidae). Typical orb-weavers // The fauna of India. Spiders: Araneae. Vol.2. Calcutta: Zoological Survey of India. 293 p.

Tikader B.K., Bal A. 1981. Studies on some orb-weaving spiders of the genera Neoscona Simon and Araneus Clerck of the family Araneidae (=Argiopidae) from India // Records of the Zoological Survey of India, Occasional Paper. Vol.24. P.1-60.

WSC. 2020. World Spider Catalog. Version 21.0. Natural History Museum Bern, online at http://wsc.nmbe.ch, accessed on 9.6.2020. doi: $10.24436 / 2$

Yin C.M., Wang J.F., Zhu M.S. Xie L.P., Peng X.J., Bao Y.H. 1997. Fauna Sinica: Arachnida: Araneae: Araneidae. Beijing: Science Press. 460 pp.

Zamani A., Marusik Yu.M., Šestáková A. 2020. On Araniella and Neoscona (Araneae, Araneidae) of the Caucasus, Middle East and Central Asia // ZooKeys. Vol.906. P.13-40.

Responsible editor K.G. Mikhailov 